OPEN ACCESS

Edited by:

Eliane Dallegrave,

Federal University of Health Sciences

of Porto Alegre, Brazil

Reviewed by:

Helena Cristina Silva de Assis,

Federal University of Paraná, Brazil

Lucas Paschoal,

São Paulo State Technological

College, Brazil

Luciana Grazziotin Grando,

The University of Passo Fundo, Brazil

*Correspondence:

Enrique M. Rodríguez

enrique@bg.fcen.uba.ar

Specialty section:

This article was submitted to

Translational Endocrinology,

a section of the journal

Frontiers in Endocrinology

Received: 17 December 2020

Accepted: 24 February 2021

Published: 26 March 2021

Citation:

Rodríguez EM, Medesani DA, Canosa IS and Avigliano L (2021) The

Effect of Glyphosate on the

Reproduction of Estuarine Crabs: Neohelice granulata as a Study Model.

Front. Endocrinol. 12:643168.

doi: 10.3389/fendo.2021.643168

\section{The Effect of Glyphosate on the} Reproduction of Estuarine Crabs: Neohelice granulata as a Study Model

\author{
Enrique M. Rodríguez ${ }^{1 *}$, Daniel A. Medesani ${ }^{1}$, Ivana S. Canosa ${ }^{1}$ and Luciana Avigliano ${ }^{2}$ \\ ${ }^{1}$ Laboratorio de Fisiología de Crustáceos, Universidad de Buenos Aires, CONICET, Instituto de Biodiversidad y Biología \\ Experimental y Aplicada (IBBEA), Facultad de Ciencias Exactas y Naturales, Departamento de Biodiversidad y Biología \\ Experimental, Ciudad Universitaria, Buenos Aires, Argentina, 2 Instituto del Conurbano-Universidad Nacional de General \\ Sarmiento (ICO-UNGS), CONICET, Los Polvorines, Argentina
}

This review summarizes the bulk of evidence about the effect of glyphosate, both technical and formulated, on the ovarian maturation of Neohelice granulata female crabs, as well as the effects of glyphosate on sperm production in males of the same species. After longterm in vivo assays, made during the 3-month pre-reproductive period of this species, both formulated and technical glyphosate were able to produce a significant incidence of oocyte reabsorption in the ovary, together with a concomitant decreased of vitellogenin content, at concentrations ranging from 0.2 to $1 \mathrm{mg} / \mathrm{L}$. Despite this, after 32-day in vivo assays, glyphosate stimulated oocyte growth, in terms of a higher percentage of vitellogenic oocytes, suggesting that glyphosate could be acting as an endocrine disruptor. In vitro assays made with isolated ovarian pieces showed a decrease of vitellogenin content, in correlation with lower protein synthesis, although some advance in maturation was observed in the histological analysis. In male crabs exposed in vivo to both technical and formulated glyphosate at $1 \mathrm{mg} / \mathrm{L}$, several reproductive imbalances were noted, such as a significant decrease of the sperm count, abnormal spermatophores, and possible disrupting effects of glyphosate on the androgenic gland.

Keywords: Roundup Ultramax ${ }^{\circledR}$, crabs, ovary, herbicide, reproductive aspects, spermatozoa

\section{INTRODUCTION}

Glyphosate [N-(phosphonomethyl) glycine] is currently the most widely used herbicide worldwide (1). This is a non-selective, systemic herbicide that inhibits the enzyme 5-enolpyruvylshikimate-3phosphate synthase, involved in the aromatic amino acid synthesis in plants (2). In the last two decades, the use of glyphosate in Argentina has increased exponentially, mainly on transgenic soy resistant to glyphosate $(3,4)$. Consequently, environmental levels of glyphosate have been reported to range between 0.1 and $0.7 \mathrm{mg} / \mathrm{L}$ in water and between 0.5 and $5 \mathrm{mg} / \mathrm{kg}$ in sediment (5).

Crustaceans are a highly representative group of the invertebrate aquatic fauna susceptible to be impacted by glyphosate (6). In particular, Neohelice granulata (Dana, 1851) is a widespread estuarine crab species, distributed along the Atlantic coast of both Argentina and Brazil. In 
Argentina, this species forms very dense populations along the entire coast of Samborombon Bay, corresponding to the external zone of the "Rio de la Plata" estuary, also being a relevant link in the trophic web that includes several fish species that reproduce there (7). This Bay, as well as other sites inhabit by N. granulata, received the discharge of several rivers and channels that cross extensive agricultural areas and carry significant amounts of pesticides, including herbicides (8). Moreover, glyphosate is more intensively applied to both soybean and corn crops during summer, coinciding with the reproductive period of $N$. granulata (9).

The reproductive cycle of $N$. granulata comprises three periods (9): pre-reproductive (winter), during which the ovary grows and mature; reproductive (spring and summer), when both spawning and hatching occur, and eventually the ovarian re-maturation takes place to produce further spawns; and finally the post-reproductive period (autumn), which leads to both ovarian quiescent and molting of adults. In addition to the production of vitellogenin by the oocytes themselves (primary vitellogenesis), during the pre-reproductive period, the ovary enters into the secondary vitellogenesis, which implies an active uptake by maturing oocytes of the vitellogenin synthesized both in the hepatopancreas and the ovary $(10,11)$. Vitellogenin is the precursor of vitellins, the main lipoproteins of the yolk. After spawning, hatching, and larval development, the megalopa returns to the coast, molting successively to several juvenile instars, and finally reaching the adult condition (9).

Crustacean vitellogenesis is under hormonal control; to this respect, several neurohormones by the thoracic ganglion, brain, and the $\mathrm{X}$ organ-sinus gland complex located at the eyestalks are involved (12). These neurohormones, in turn, regulate the secretion of other hormones of non-peptidic nature; one of them is represented by vertebrate-like steroids such as 17hydroxyprogesterone, likely secreted by the ovaries $(11,13)$; moreover, progesterone receptors have been identified in the ovary and other tissues of shrimps and crabs $(14,15)$. Besides, methyl farnesoate, the juvenile crustacean hormone secreted by the mandibular organ, as well as prostaglandins, have been reported as other stimulating hormones of crustacean reproduction $(12,16,17)$. In males, the endocrine regulation of spermatogenesis is mainly carried out by the androgenic gland, a bilateral organ attached to the distal region of the vasa deferentia (18), which secretes the "androgenic gland hormone", belonging to the insulin family, under the control of the neurohormones secreted by both eyestalks and thoracic ganglion $(11,19)$.

Relatively few studies on the deleterious effect of glyphosate on crustacean reproduction have been published, in comparison with the literature available for other aquatic species, such as fishes. Concerning the role of glyphosate as a possible endocrine disruptor, some evidence on the interference of this herbicide with the synthesis of several sexual steroids has been also reported in animal models other than crustaceans $(1,20,21)$. This review is aimed at summarizing the deleterious effects of glyphosate, both technical and formulated, on the reproduction of the crab $N$. granulata, taken as a representative model of higher crustaceans. For this, the results of both in vivo and in vitro assays are presented. Among the imbalances caused by glyphosate, several pieces of evidence about the endocrine disruption exerted by this herbicide are discussed, in both females and males.

\section{IN VIVO EFFECTS ON FEMALE CRABS}

A first in vivo assay carried out with technical glyphosate during the entire pre-reproductive period (3 months), showed a significant incidence of oocyte reabsorption, but just at the highest glyphosate concentration tested $[\sim 35 \%$ in $1 \mathrm{mg} / \mathrm{L}$ concentration, Figure 2 in (22), Figure 1A here]. A further in vivo assay, made during the same period with the commercial glyphosate formulation Roundup Ultramax ${ }^{\circledR}$, also showed a significant incidence of oocyte reabsorption in the ovary, together with decreased vitellogenic protein content by gram of ovary; these results were found in females exposed to $0.2 \mathrm{mg} / \mathrm{L}$ of glyphosate presented as the active ingredient in the commercial formulation above mentioned [Figures 2 and 3 in (23), Figure 1B here]. Based on the results of these long-term assays, contributive toxicity of the coadjuvants presented in the commercial formulation seems to have been occurred.

A third in vivo assay was made during the first part of the reproductive period (spring), with re-maturating females, i.e., females that became ovigerous at the beginning of this period, whose ovaries entered at the same time in a re-maturation phase, in order to produce a second spawn. After exposing posthatching females for 32 days to both technical and formulated (Roundup Ultramax ${ }^{\circledR}$ ) glyphosate, a significant advanced oocyte growth was seen with technical glyphosate, in terms of a higher percentage of vitellogenic (more mature) oocytes [Figure 5B-C and Table 2 in $(24,25)$, Figure 1C here]. Besides, oocyte reabsorption was observed in all treatments (although with some higher incidence in the glyphosate treatments than in the control), because the remnant of oocytes not released in the previous spawn was under reabsorption in all females.

\section{IN VITRO EFFECTS ON FEMALE CRABS}

In vitro assays comprised the incubation of isolated ovarian pieces for 24 hours, in small vials with an appropriate culture medium, and into a culture chamber. After incubating isolated pieces of ovary with Roundup Ultramax ${ }^{\circledR}$, at the same glyphosate concentration that showed deleterious effects in vivo $(0.2 \mathrm{mg} / \mathrm{L})$, a decrease in vitellogenin content was also seen. Moreover, by means of evaluating the incorporation of a radiolabeled amino acid to the ovarian proteins, it could be established that partial inhibition of the protein synthesis was caused by Roundup Ultramax $^{\circledR}$ [Figure 6 in (23), Figure 2A here], accounting for the decreased vitellogenin content observed in vitro. Short-term changes in vitellogenic protein content (either increase or decrease) have been also observed by effect of other pollutants, and even hormones, in several in vitro assays made on 

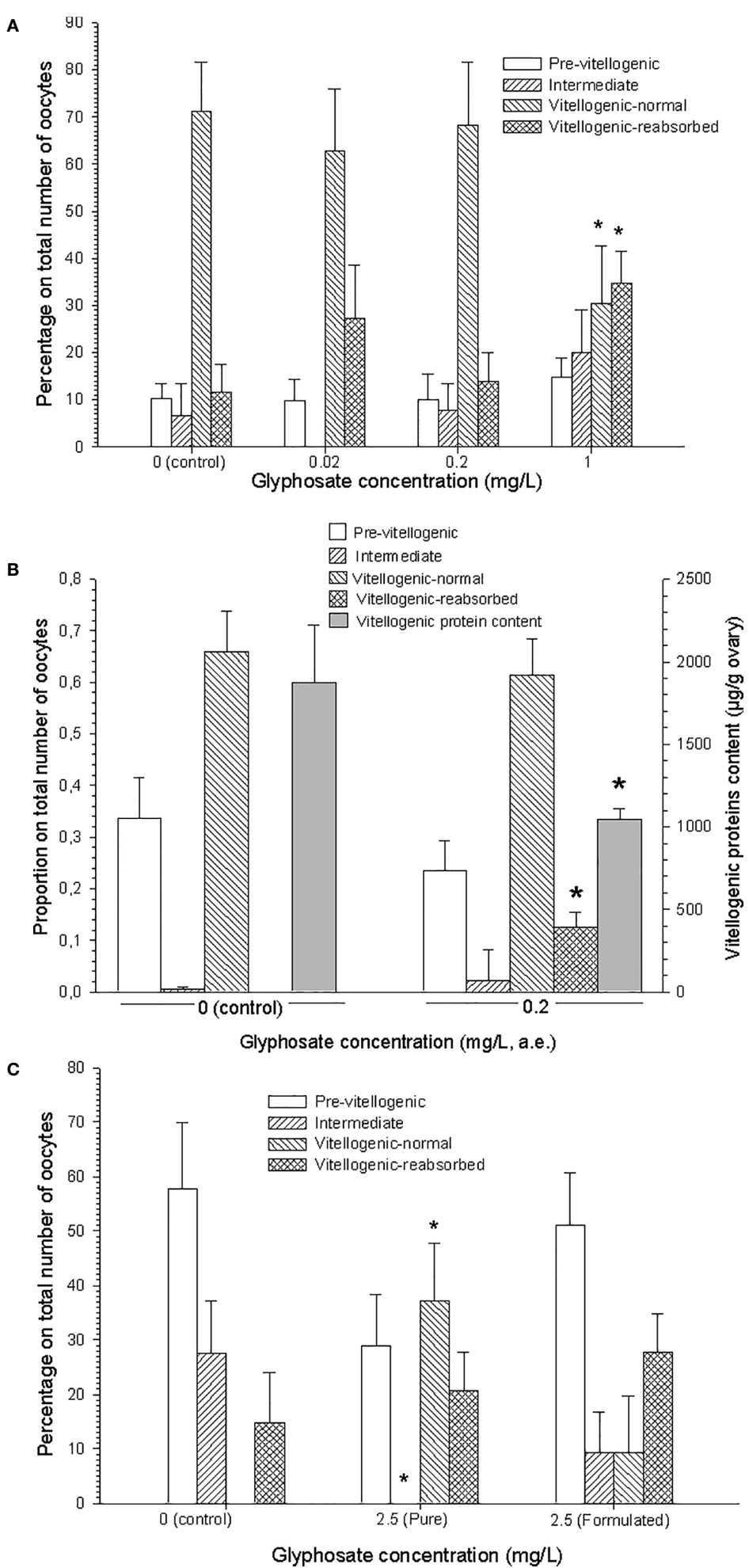

FIGURE 1 | Results from in vivo assays made with glyphosate on the crab Neohelice granulata. (A) Assay made with technical glyphosate during the entire (3-months) pre-reproductive period. Reproduced from Avigliano et al. (22). (B) Assay made with Roundup Ultramax ${ }^{\circledR}$ during the same period. Adapted from Canosa et al. (23). (C) Assay made with both technical and formulated (Roundup Ultramax ${ }^{\circledR}$ ) glyphosate, during 32 days, in post-hatching females. Redrawn from Avigliano et al. $(24,25)$. In all cases, glyphosate concentrations are expressed as acid equivalents (a.e.); oocyte types are indicated; asterisks indicate significant differences $(p<0.05)$ with respect to control. All figures are reproduced or adapted with permission. 

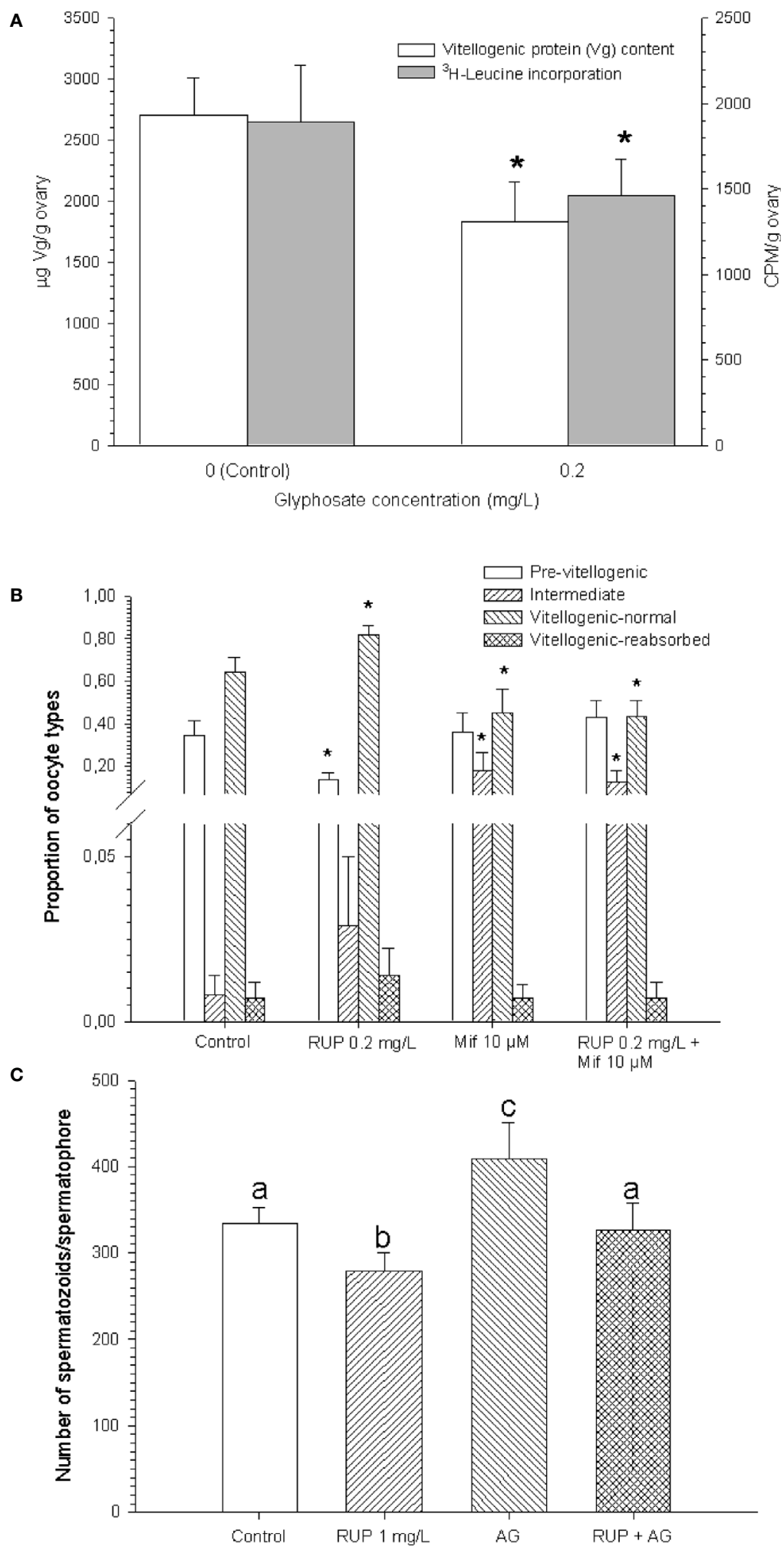

FIGURE 2 | Results from in vitro assays made with formulated glyphosate (RUP: Roundup Ultramax ${ }^{\circledR}$ ) on the crab Neohelice granulata. (A) Vitellogenic protein (Vg) content, and ${ }^{3} \mathrm{H}$-leucine incorporation. Adapted from Canosa et al. (23). (B) Histological analysis; oocyte types are indicted; Mif, mifepristone. Redrawn from Canosa et al. (26). (C) Sperm count in males; AG, androgenic gland. Reproduced from Canosa et al. (27, 28). In all cases, glyphosate concentrations are expressed as acid equivalents (a.e.); asterisks, as well as different lowercase letters, indicate signficant differences $(p<0.05)$ with respect to control. All figures are reproduced or adapted with permission. 
N. granulata and other crustacean species $(24,25,29-32)$. The vitellogenin synthesis can certainly rapidly detected; as reported by Reddy Buchi et al. (33), the expression of vitellogenin ARNm occurred as early as 3 hours after beginning the in vitro incubation of crab hepatopancreas.

Another in vitro assay made with technical glyphosate at $0.2 \mathrm{mg} / \mathrm{L}$ showed an abnormal increase in the size of the immature (previtellogenic) oocytes, an effect also observed in vivo (22, data not shown). These results suggest that glyphosate could stimulate the secretion of any stimulating hormone produced by the ovary, such as some kind of ovarian steroid $(11,34)$, or could be acting as a steroidal agonist, by binding to steroid receptors at the ovary. To check this latter hypothesis, a histological analysis was done after a $24 \mathrm{~h}$-incubation of ovarian pieces with Roundup Ultramax ${ }^{\circledR}(0.2 \mathrm{mg} / \mathrm{L})$, mifepristone $10 \mu \mathrm{M}$ (an antagonist of progesterone receptors), or the combination of Roundup and mifepristone. This antagonist, either alone or in combination with Roundup, inhibited the oocyte's maturation, although Roundup alone was able to stimulate it [Figure 3 in (26), Figure 2B here]. Although Roundup per se stimulated the ovarian maturation, in terms of an increased proportion of vitellogenic oocytes, it also reduced the area of these oocytes [Table 1 in (26), data not shown], which was in agreement with the lower vitellogenic protein content observed by the effect of Roundup in the previous in vitro assay mentioned.

These later results, together with the advanced re-maturation observed in vivo after 32-days of exposure, are consistent with a possible endocrine-disrupter effect caused by glyphosate, likely altering the secretion and/or the transductional mechanism of one or more hormones controlling the ovarian growth in crustaceans.

\section{EFFECTS ON MALE CRABS}

Neohelice granulata male crabs exposed for $30 \mathrm{~d}$ to $1 \mathrm{mg} / \mathrm{L}$ of either technical or formulated glyphosate, showed a significant decrease in weight gain and muscle protein levels, a result previously observed in juveniles of the crayfish Cherax quadricarinatus (35-37). Besides, in spermatophores from the vasa deferentia of those $N$. granulata males, a significant decrease of the sperm count was observed by effect of Roundup Ultramax ${ }^{\circledR}$, while a significant incidence of abnormal spermatophores was observed either with technical glyphosate or Roundup treatment $(27,28)$. Moreover, after incubating testes and vasa deferentia with Roundup Ultramax ${ }^{\circledR}$, with or without the presence of the androgenic gland, the increase in the number of spermatozoa/spermatophore produced by the co-incubation with this endocrine gland was completely reverted by the addition of Roundup [Figure 5 in $(27,28)$, Figure $\mathbf{2 C}$ here].

\section{DISCUSSION AND CONCLUSIONS}

The concentrations used in the in vivo assays were within the environmental range of glyphosate reported for several water bodies of Argentina $(5,38)$. The deleterious effects on the ovarian growth were observed at $0.2 \mathrm{mg} / \mathrm{L}$ of glyphosate (as active ingredient in Roundup Ultramax), a concentration lower than the $0.7 \mathrm{mg} / \mathrm{L}$ reported for argentine most impacted areas (5). Besides, glyphosate application in Argentina has been steadily increasing over time (3); more than 20 million ha (mainly soybean crops) are currently treated with approximately 200 million liters of glyphosate (5). Since glyphosate has not shown to be acutely toxic for aquatic fauna, its chronic accumulative effects represent a critical issue to be studied. Certainly, this has been the focus of our in vivo studies on the estuarine crab $N$. granulata, during the entire period of ovarian growth. Besides, since several undeclared surfactants have been used during the last years to formulate Roundup and other trademarks (1), the study of the deleterious effects caused by technical glyphosate represents useful information for evaluating the toxicity of any commercial formulation of this herbicide.

The decrease in vitellogenin content observed in vitro with $0.2 \mathrm{mg} / \mathrm{L}$ of glyphosate (in the Roundup Ultramax ${ }^{\circledR}$ formulation), was related to an inhibitory effect of the herbicide on the vitellogenic protein synthesis, as also observed in vitro. Moreover, the results of the 90-days in vivo assays, either made with Roundup Ultramax ${ }^{\circledR}$ at $0.2 \mathrm{mg} / \mathrm{L}$ or with technical glyphosate at $1 \mathrm{mg} / \mathrm{L}$, showed significant oocyte reabsorption. Reactional oocyte atresia has been observed in previous studies made on N. granulata females exposed to several pollutants (3942). In this kind of atresia, follicular cells that surround the vitellogenic oocytes invade them to phagocyte the vitellum. Interestingly, atretic oocytes have also been reported in several frog species chronically exposed to either 0.6 or $1.8 \mathrm{mg} / \mathrm{L}$ (a.e.) of the original Roundup ${ }^{\circledR}$ formulation (43).

Within an in vivo context, the reabsorption of yolk could be a compensatory mechanism when a reduction in somatic growth is taking place as a result of stressful situations (44). In fact, in those females exposed to technical glyphosate for three months, a decrease in the body weight gain was observed at all concentrations assayed (22). In addition, early juveniles of the crayfish C. quadricarinatus exposed to technical glyphosate (10 and $40 \mathrm{mg} / \mathrm{L}$ ) also showed a decreased body weight gain, in correlation with lower levels of both protein and lipid reserves $(36,37)$. Advanced juveniles of the same species also showed a growth reduction after being exposed to 15 $\mathrm{mg} / \mathrm{L}$ of a mixture of glyphosate with polyoxyethylenamine, the surfactant used in the original formulation of Roundup ${ }^{\circledR}$ (35). This formulation was also able to reduce the growth rate of freshwater shrimps exposed for 40 days to concentrations ranging from 2.2 to $5.4 \mathrm{mg} / \mathrm{L}(36,37)$. Another glyphosate formulation inhibited the growth of the first copepodite stage, preventing copepods to reach the adult stage, these effects being observed at a glyphosate concentration of $0.81 \mathrm{mg} / \mathrm{L}(27,28)$.

Some hormones belonging to the $\mathrm{CHH}$-family of peptides, produced and secreted at the eyestalks, could be involved in oocyte reabsorption. The $\mathrm{CHH}$ (crustacean hyperglycemic hormone) has been considered as the "stress hormone" of crustaceans (45), and some effects on the ovary of different isoforms of $\mathrm{CHH}$ have been also reported in several crustacean species $(46,47)$. Another hormone of this family, the GIH (gonad inhibiting hormone) would prevent the maturation of 
pre-vitellogenic oocytes to vitellogenic ones (12). If the titers of this inhibitory hormone were high when the ovary is maturating, it is plausible to suppose that vitellogenic oocytes could be suffering reabsorption. Interestingly, glyphosate was able to increase oocyte reabsorption when eyestalk tissue was added to ovarian pieces in vitro (22, data not shown).

However, an advanced ovarian maturation, in terms of a higher proportion of vitellogenic oocytes, was seen after the 32 days-long in vivo assay with re-maturating females. Nevertheless, by comparing this result with the inhibition of ovarian growth observed after the long-term (90 days) in vivo assay, the stimulating effect observed after 32 days seems to have been overcome after 90 days of exposure, when the oocyte reabsorption and the consequent decrease in the vitellogenic protein content were evident, as compared to control. Stimulation of ovarian growth has been also seen in $N$. granulata females exposed to the organophosphate insecticide parathion, in terms of a larger size of both previtellogenic and vitellogenic oocytes (39). Indeed, the abnormal acceleration of ovarian growth observed with either glyphosate or parathion strongly suggests that these pesticides are able to act as endocrine disruptors in crustaceans.

In this respect, an interference with the endocrine control of ovarian maturation exerted by steroids could be a serious possibility to be considered, and in this sense, the results from the in vitro assay with mifepristone suggest that glyphosate could act as a "xenoprogestagen", facilitating the transductional pathway of progesterone at some step, or eventually enhancing the synthesis of progesterone by the ovary, in order to produce a higher proportion of vitellogenic oocyte. Progesterone, among other steroids, has been suggested to play different roles in the ovarian maturation of crustaceans, other than that strictly related to the synthesis of vitellogenic proteins (34). Taken together, the results from the in vitro assays indicate that glyphosate could exert a direct effect on the ovary by inhibiting the synthesis of vitellogenic proteins to some extent, as mentioned earlier, but at the same time it could produce an advanced maturation by potentiating the effect of some steroid hormones secreted by the ovary, such as progesterone. However, the exact mechanism by which glyphosate and/or the other components of the glyphosate formulation assayed would directly affect the maturation process in the ovary needs further research. Besides, the extrapolation of the results obtained in vitro to the in vivo conditions should be carefully made, since the in vivo physiological context is certainly more complex, and therefore a lot of interacting effects should be taking into account.

The endocrine control of reproduction in crustacean males has been relatively less studied than in females. However, it is well known, as mentioned previously, that the androgenic glands attached to the vasa deferentia are responsible for secreting a peptidic hormone that regulates sexual differentiation and spermatogenesis $(11,19)$. The in vitro suppression caused by Roundup Ultramax ${ }^{\circledR}$ on the increased number of spermatozoa stimulated by the androgenic gland, suggests that inhibition of the secretion and/or transduction of the androgenic gland hormone could have been caused by this glyphosate formulation, in addition to some other deleterious effects caused by the herbicide, such as abnormal spermatophores.
Comparatively, fish exposed to $3.6 \mathrm{mg} / \mathrm{L}$ of the original Roundup ${ }^{\circledR}$ formulation, showed a reduction in sperm quality (48).

Evidence about de-masculinization of crustacean males has been reported for some anthropogenic agents. For instance, a lower proportion of males, together with a higher incidence of intersex, were seen in amphipods exposed to industrial effluents in natural environments (49). Moreover, Mac Loughlin et al. (50) have reported a decrease in the proportion of males in early juveniles of the crayfish C. quadricarinatus exposed to the herbicide atrazine during the critical period of sexual differentiation. As seen on $N$. granulata exposed both in vivo and in vitro to glyphosate, a possible interference of several other pollutants with the endocrine control exerted by the androgenic gland is quite possible.

In summary, taking into account the whole evidence obtained from the estuarine crab N. granulata exposed to glyphosate, both technical and formulated, we can conclude the following:

- Glyphosate is able to inhibit the ovarian growth of N. granulata females during the 90-days needed for fully ovarian growth, producing a higher incidence of oocyte reabsorption together with decreased vitellogenic protein content. Since these effects were observed at $0.2 \mathrm{mg} / \mathrm{L}$ of glyphosate in the Roundup Ultramax ${ }^{\circledR}$ formulation, and just at $1 \mathrm{mg} / \mathrm{L}$ of technical glyphosate, the contributive toxicity of the coadjuvants presented in the commercial formulation was evident.

- At a shorter time of exposure (32 days) glyphosate is able to produce an advanced maturation, but only in terms of a higher proportion of vitellogenic oocytes.

- The results of the short-term in vitro assays with isolated ovarian pieces indicate an inhibitory effect of glyphosate on the synthesis of vitellogenic proteins, but also a stimulating effect on the progress of maturation, in terms of a higher proportion of vitellogenic oocytes, likely by enhancing the effect of ovarian steroids such as progesterone.

\section{AUTHOR CONTRIBUTIONS}

ER: supervision of all the studies presented and wrote the manuscript. DM: coordination and supervision of all the in vitro experiments and collaboration in the in vivo experiments. IC and LA: conduction of experiments and also a PhD student. All authors contributed to the article and approved the submitted version.

\section{FUNDING}

The experimental work on $N$. granulata referred to in the present review, was supported by grants from ANPCyT (PICT2010-0908, and PICT2016-0040), CONICET (PIP2010-0908, code 100884, and PIP2015, code 11220150100100CO), and the University of Buenos Aires (UBACYT 2016-2018, code 20020150100060BA, and UBACYT 2020, code 20020190100014BA). 


\section{REFERENCES}

1. Mesnage R, Defarge N, Spiroux de Vendômois J, Séralini GES. Potential toxic effects of glyphosate and its commercial formulations below regulatory limits. Food Chem Toxicol (2015) 84:133-53. doi: 10.1016/j.fct.2015.08.012

2. Lydon J, Duke SO. Pesticide effects on secondary metabolism of greater plants. Pestic Sci (1989) 25:361-73. doi: 10.1002/ps.2780250406

3. Arancibia F. Challenging the bioeconomy: The dynamics of collective action in Argentina. Technol Soc (2013) 35:79-22. doi: 10.1016/j.techsoc.2013.01.008

4. Leguizamon A. Modifying Argentina: GM soy and socio-environmental change. Geoforum (2014) 53:149-60. doi: 10.1016/j.geoforum.2013.04.001

5. Peruzzo PJ, Porta AA, Ronco AE. Levels of glyphosate in surface waters, sediments and soil associated with direct sowing soybean cultivation in north pampasic region of Argentina. Environ Pollut (2008) 156:61-6. doi: 10.1016/ j.envpol.2008.01.015

6. Van Bruggen AHC, He MM, Shin K, Mai V, Jeong KC, Finckh MR, et al. Environmental and health effects of the herbicide glyphosate. Sci Total Environ (2018), 616-617, 255-68. doi: 10.1016/j.scitotenv.2017.10.309

7. Sánchez F, Mari N, Lasta C, Giangioble A. Alimentación de la corvina rubia (Micropogonias furnieri) en la Bahía de Samborombón. Frente Marítimo (1991) 8:43-50. Available at: http://ctmfm.org/upload/archivoSeccion/ sanchez-et-al-143135472511.pdf.

8. Comisión Administradora del Río de la Plata. Estudio para la evaluación de la contaminación en el Río de la Plata. Buenos Aires: Argentine Hydrographic Service Navy (1990).

9. López Greco LS, Rodríguez EM. Annual reproduction and growth of adult crabs, Chasmagnathus granulata (Crustacea, Brachyura, Grapsidae). Cah Biol Mar (1999) 40:155-64. doi: 10.21411/CBM.A.DDA75B30

10. Li K, Chen L, Zhou Z, Li E, Zhao X, Guo H. The site of vitellogenin synthesis in Chinese mitten-handed crab Eriocheir sinensis. Comp Biochem Physiol (2006) 143B:453-8. doi: 10.1016/j.cbpb.2005.12.019

11. Nagaraju GPC. Reproductive regulators in decapods crustaceans: An overview. J Exp Biol (2011) 214:3-16. doi: 10.1242/jeb.047183

12. Fingerman M. Roles of neurotransmitters in regulating reproductive hormone release and gonadal maturation in decapod crustaceans. Invertebr Reprod Dev (1997) 31:47-54. doi: 10.1080/07924259.1997.9672562

13. Lafont R, Mathieu M. Steroids in aquatic invertebrates. Ecotoxicology (2007) 16:109-30. doi: 10.1007/s10646-006-0113-1

14. Preechaphol R, Klinbunga S, Ponza P, Menasveta P. Isolation and characterization of progesterone receptor-related protein p23 (Pm-p23) differentially expressed during ovarian development of the giant tiger shrimp Penaeus monodon. Aquaculture (2010) 308:S75-82. doi: 10.1016/j.aquaculture.2010.06.037

15. Ye H, Huang H, Song P. The identification and distribution of progesterone receptors in the brain and thoracic ganglion in the mud crab Scylla paramamosain (Crustacea: Decapoda: Brachyura). Invert Neurosci (2010) 10:1-16. doi: 10.1007/s10158-010-0100-3

16. Rodríguez EM, Medesani DA, Fingerman M. Endocrine disruption in crustaceans due to pollutants: A review. Comp Biochem Physiol (2007) 146A:661-71. doi: 10.1016/j.cbpa.2006.04.030

17. Han S, Choi K, Kim J, Ji K, Kim S, Ahn B, et al. Endocrine disruption and consequences of chronic exposure to ibuprofen in Japanese medaka (Oryzias latipes) and freshwater cladocerans Daphnia magna and Moina macrocopa. Aquat Toxicol (2010) 98:256-64. doi: 10.1016/j.aquatox.2010.02.013

18. Subramonian T. Sexual Biology and Reproduction in Crustaceans. New York: Academic Press (2017).

19. Ventura T, Rosen O, Sagi A. From the discovery of the crustacean androgenic gland to the insulin-like hormone in six decades. Gen Comp Endocrinol (2011) 173:381-8. doi: 10.1016/j.ygcen.2011.05.018

20. Quassinti L, Maccari E, Murri O, Bramucci M. Effects of paraquat and glyphosate on steroidogenesis in gonads of the frog Rana esculenta in vitro. Pest. Biochem Physiol (2009) 93:91-5. doi: 10.1016/j.pestbp.2008.11.006

21. Richard S, Moslemi S, Sipahutar H, Benachour N, Seralini GE. Differential effects of glyphosate and roundup on human placental cells and aromatase. Environ Health Perspect (2005) 113:716-20. doi: 10.1289/ehp.7728

22. Avigliano L, Canosa IS, Medesani DA, Rodriguez EM. Effects of glyphosate on somatic and ovarian growth in the estuarine crab Neohelice granulata, during the pre-reproductive period. Water Air Soil Pollut (2018) 229:44. doi: 10.1007/ s11270-018-3698-0
23. Canosa IS, Silveyra GR, Avigliano L, Medesani DA, Rodriguez EM. Ovarian growth impairment after chronic exposure to Roundup Ultramax ${ }^{\circledR}$, in the estuarine crab Neohelice granulata. Environ Sci Pollut Res (2018) 25:1568-75. doi: 10.1007/s11356-017-0581-2

24. Avigliano L, Álvarez NB, Mac Loughlin C, Rodríguez EM. Effects of glyphosate on egg incubation, larvae hatching and ovarian re-maturation, in the estuarine crab Neohelice granulata. Environ Toxicol Chem (2014) 33:1879-84. doi: 10.1002/etc.2635

25. Cahansky AV, Medesani DA, Chaulet A, Rodríguez EM. In vitro effects of both dopaminergic and enkephalinergic antagonists on the ovarian growth of Cherax quadricarinatus (Decapoda, Parastacidae), at different periods of the reproductive cycle. Comp Biochem Physiol (2011) 158A:126-31. doi: 10.1016/ j.cbpa.2010.09.016

26. Canosa IS, Silveyra GR, Lonné MN, Medesani DA, Rodriguez EM. In vitro interference of a glyphosate commercial formulation with the stimulation of ovarian maturation by progesterone, in the estuarine crab Neohelice granulata. Bull Environ Contam Toxicol (2021). doi: 10.1007/s00128-021-03107-9

27. Canosa IS, Zanitti M, Lonne N, Medesani DA, Lopez Greco LS, Rodriguez EM. Imbalances in the male reproductive function of the estuarine crab Neohelice granulata, caused by glyphosate. Ecotoxicol Environ Saf (2019) 182:109405. doi: 10.1016/j.ecoenv.2019.109405

28. Fantón N, Bacchetta C, Rossi A, Gutierrez MF. Effects of a glyphosate-based herbicide on the development and biochemical biomarkers of the freshwater copepod Notodiaptomus carteri (Lowndes, 1934). Ecotoxicol Environ Saf (2020) 196:110501. doi: 10.1016/j.ecoenv.2020.110501

29. Rodríguez EM, López Greco LS, Fingerman M. Inhibition of ovarian growth by cadmium, in the fiddler crab Uca pugilator (Decapoda, Ocypodidae). Ecotoxicol Environ Saf (2000) 46:202-6. doi: 10.1006/eesa.1999.1896

30. Rodríguez EM, López Greco LS, Medesani DA, Laufer H, Fingerman M. Effect of methyl farnesoate, alone and in combination with other hormones, on ovarian growth of the red swamp crayfish, Procambarus clarkii, during vitellogenesis. Gen Comp Endocrinol (2002) 125:34-40. doi: 10.1006/gcen.2001.7724

31. Zapata V, López Greco LS, Rodríguez EM. Effect of copper on hatching and development of larvae of the estuarine crab Chasmagnathus granulata (Decapoda, Brachyura). Environ Toxicol Chem (2001) 20:1579-83. doi: 10.1016/S0044-8486(03)00226-6

32. Eastman-Reks SB, Fingerman M. In vitro synthesis of vitellin by the ovary of the fiddler crab Uca pugilator. J Exp Zool (1985) 233:111-6. doi: 10.1002/ jez.1402330115

33. Reddy Buchi S, Vaadala S, Hosamani N, Reddy Pamuru R, Reddy Pamanji S. Regulation of vitellogenesis by selected endocrine modulators in crab Oziothelphusa senex senex, with special reference to methyl farnesoate. Aquacult Rep (2016) 3:24-30. doi: 10.1016/j.aqrep.2015.11.006

34. Subramonian T. Steroidal control of vitellogenesis in Crustacea: a new understanding for improving shrimp hatchery production. Proc Indian Natl Sci Acad (2017b) 83:595-610. doi: 10.16943/ptinsa/2017/48969

35. Frontera JL, Vatnick I, Chaulet A, Rodríguez EM. Effects of glyphosate and polyoxyethylenamine on growth and energetic reserves in the freshwater crayfish Cherax quadricarinatus (Decapoda, Parastacidae). Arch Environ Contam Toxicol (2011) 61:590-8. doi: 10.1007/s00244-011-9661-3

36. Avigliano L, Fassiano AV, Medesani DA, Ríos de Molina MC, Rodríguez EM. Effects of glyphosate on growth rate, metabolic rate and energy reserves of early juvenile crayfish, Cherax quadricarinatus M. Bull Environ Contam Toxicol (2014) 92:631-5. doi: 10.1007/s00128-014-1240-7

37. Mensah PK, Muller WJ, Palmer CG. Using growth measures in the freshwater shrimp Caridina nilotica as biomarkers of Roundup pollution of South African freshwater systems. Phys Chem Earth (2012) 50-52:262-8. doi: 10.1016/j.pce.2012.08.003

38. Aparicio VC, De Gerónimo E, Marino D, Primost J, Carriquiriborde P, Costa JL. Environmental fate of glyphosate and aminomethylphosphonic acid in surface waters and soil of agricultural basins. Chemosphere (2013) 93:1866-73. doi: 10.1016/j.chemosphere.2013.06.041

39. Rodríguez EM, Schuldt M, Romano L. Chronic histopathological effects of parathion and 2,4-D on female gonads of Chasmagnathus granulata (Decapoda, Brachyura). Food Chem Toxicol (1994) 32:811-8. doi: 10.1016/ 0278-6915(94)90157-0

40. Kogan M, López Greco LS, Romano LA, Rodríguez EM. Effects of cadmium on somatic and gonadal growth of juvenile females of the estuarine crab 
Chasmagnathus granulata (Brachyura, Grapsidae). Zool Stud (2000) 39:34450. http://zoolstud.sinica.edu.tw/Journals/39.4/344.pdf.

41. Álvarez NB, Avigliano L, Mac Loughlin C, Rodríguez EM. Atrazine impairs reproduction in the estuarine crab Neohelice granulata. Reg Stud Mar Sci (2015) 1:1-6. doi: 10.1016/j.rsma.2014.12.001

42. Silveyra GR, Canosa IS, Rodriguez EM, Medesani DA. Effects of atrazine on ovarian growth, in the estuarine crab Neohelice granulata. Comp Biochem Physiol (2017) 192C:1-6. doi: 10.1016/j.cbpc.2016.10.011

43. Howe CM, Berrill M, Pauli BD, Helbing CC, Werry K, Veldhoen N. Toxicity of glyphosate-based pesticides to four North American frog species. Environ Toxicol Chem (2004) 23:1928-38. doi: 10.1897/03-71

44. Sokolova IM, Frederich M, Bagwe R, Lannig G, Sukhotin AA. Energy homeostasis as an integrative tool for assessing limits of environmental stress tolerance n aquatic invertebrates. Mar Environ Res (2012) 79:1-15. doi: 10.1016/j.marenvres.2012.04.003

45. Chang ES, Chang SA, Keller R, Reddy PS, Snyder MJ, Spees JL. Quantification of stress in lobsters: Crustacean hyperglycemic hormone, stress protein and gene expression. Am Zool (1999) 39:487-95. doi: 10.1093/icb/39.3.487

46. Fanjul-Moles ML. Biochemical and functional aspects of crustacean hyperglycemic hormone in decapod crustaceans: Review and update. Comp Biochem Physiol (2006) 142C:390-400. doi: 10.1016/j.cbpc.2005.11.021

47. De Kleijn DPV, Van Herp F. Involvement of the hyperglycemic neurohormone family in the control of reproduction in decapod crustaceans. Invertebr Reprod Dev (1998) 33:263-72. doi: 10.1080/07924259.1998.9652637
48. Benck Soso A, Gil Barcellos LJ, Ranzani-Paiva MJ, Kreutz LC, Mezzalira Quevedo R, Anziliero, et al. Chronic exposure to sublethal concentration of a glyphosate-based herbicide alters hormone profiles and affects reproduction of female Jundiá (Rhamdia quelen). Environ Toxicol Pharmacol (2007) 23:308-13. doi: 10.1016/j.etap.2006.11.008

49. Ford AT, Fernandes TF, Rider SA, Read PA, Robinson CD, Davies IM. Endocrine disruption in a marine amphipod? Field observations of intersexuality and de-masculinisation. Mar Environ Res (2004) 58:169-73. doi: 10.1016/j.marenvres.2004.03.013

50. Mac Loughlin C, Canosa IS, Silveyra GR, Lopez Greco LS, Rodriguez EM. Effects of atrazine on growth and sex differentiation: in juveniles of the freshwater crayfish Cherax quadricarinatus. Ecotoxicol Environ Saf (2016) 131:96-103. doi: 10.1016/j.ecoenv.2016.05.009

Conflict of Interest: The authors declare that the research was conducted in the absence of any commercial or financial relationships that could be construed as a potential conflict of interest.

Copyright (C) 2021 Rodriguez, Medesani, Canosa and Avigliano. This is an open-access article distributed under the terms of the Creative Commons Attribution License (CC BY). The use, distribution or reproduction in other forums is permitted, provided the original author(s) and the copyright owner(s) are credited and that the original publication in this journal is cited, in accordance with accepted academic practice. No use, distribution or reproduction is permitted which does not comply with these terms. 